\title{
Role of endothelin in hypertension
}

\author{
B.K. Krämer, M. Ackermann, S.M. Kohler, G.A.J. Riegger \\ Klinik und Poliklinik für Innere Medizin II, Universität Regensburg
}

Key words: Endothelin - Human hypertension Animal models of hypertension

Since the discovery of endothelium-dependent relaxation of vascular smooth muscle [13] vascular endothelium has been recognized as an important functional unit involved in the regulation of vascular smooth-muscle tone. Relaxation results from release of a labile endothelium-derived relaxing factor probably identical to nitric oxide (reviewed in $[14,25])$. In addition to endothelium-derived relaxing factor, endothelium-derived vasoconstricting factors, with a characteristically slow onset and long duration of action, have also recently been demonstrated [16, 21, 53, 56]. In 1988 Yanagisawa et al. [76] isolated a vasoconstrictive factor from the supernatant of cultured porcine endothelial cells and determined the amino acid sequence. It had 21 amino acid residues with free amino- and carboxytermini and four cysteine residues which formed two disulfide bonds (positions 1-15 and 3-11) (Fig. 1) with a molecular weight of 2492 and was named endothelin (subsequently endothelin-1). Endothelin caused vasoconstriction of porcine right coronary artery segments with a concentration of peptide evoking $50 \%$ of maximum effect $\left(\mathrm{EC}_{50}\right)$ of $400 \mathrm{pM}$ and a maximum tension comparable to $\mathrm{KCl}$-induced contraction [76]. Sarafotoxin, the recently described venom of the burrowing asp Atractaspis engaddensis, has remarkable homology to endothelin isoforms 1-3 (Fig. 1) [31, 68]. Endothelin is formed by cleaving 164 amino acids from the 203 amino acid prepro-endothelin [by means of specific endopeptidase(s)] resulting in big endothelin (39 amino acids). Big endothelin is subsequently converted to endothelin by means of an endothelin-converting enzyme (Fig. 2).

Endothelin is now known to be a ubiquitous autacoid that is released from a number of en-

Abbreviations: $\mathrm{SHR}=$ spontaneously hypertensive rat; $\mathrm{EC}_{50}=$ concentration of peptide evoking $50 \%$ of maximum effect; DOCA $=$ deoxycorticosterone acetate dothelial cell sources, including porcine, but also from several renal cell lines, airway epithelial cells, and endometrial cells [36]. Endothelin gene transcription can be modulated in endothelial cells at the mRNA level by thrombin, adrenaline, angiotensin II, arginine vasopressin, transforming growth factor- $\beta$ (TGF- $\beta$ ), the calcium ionophores A23187 and ionomycin, phorbol esters, and shear stress; its release can be inhibited by nitric oxide or atrial natriuretic factor $[42,44]$. The endothelin gene (encoding the 212 amino acid precursor preproendothelin) has been localized to human chromosome 6 and shown to contain five exons (nucleotide sequences encoding the mature 21 amino acid endothelin-1 are contained within the second exon) [5]. Subsequently, three distinct human endothelinrelated genes (ET-1, ET-2, ET-3) have been cloned
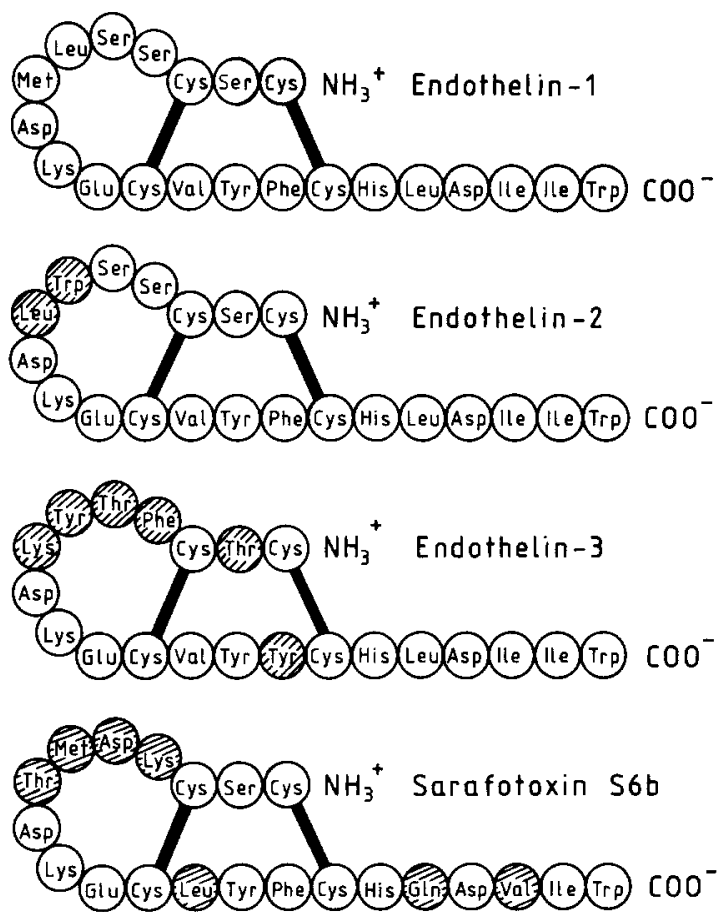

Fig. 1. Amino acid sequences of endothelin-1, endothelin-2, endothelin-3, and sarafotoxin S6b (venom of the burrowing asp Atractaspis engaddensis). Hatched circles, amino acids where endothelin-2, endothelin-3 und sarafotoxin S6b differ from endothelin-1 


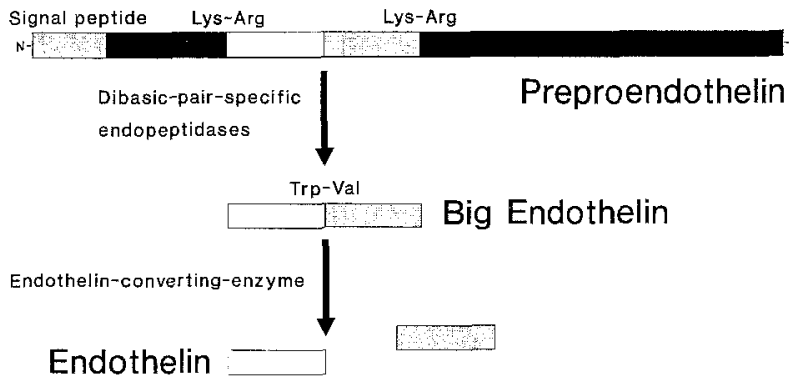

Fig. 2. Biosynthesis of endothelin. Preproendothelin is cleaved by dibasic-amino acid pair-specific endopeptidases to yield big endothelin. Big endothelin is cleaved at Trp-Val by an endothelin-converting enzyme, resulting in endothelin

by screening a human genomic DNA library under low hybridization stringency [26]. For the purpose of the present report endothelin-1 is designated as endothelin if not otherwise stated.

Because endothelin is the most potent vasoconstrictor known in man it has been hypothetized that endothelin may play an important role in hypertension. However, this question remains controversial even 5 years after isolation of the peptide. The present contribution briefly reviews data from in vitro and in vivo animal studies and studies in hypertensive patients in order to characterize the role of endothelin in hypertension.

\section{In vitro studies}

The marked vasoconstrictive effect of endothelin was first shown in porcine coronary arteries [76]. The maximum vasoconstrictive effect is comparable to that of high $\mathrm{KCl}$ and the $\mathrm{EC}_{50}$ of vasoconstriction in porcine coronary arteries is $400 \mathrm{pM}$ [76]. The vasoconstrictive effects of endothelin have been confirmed by a number of laboratories in arterial as well as venous vessels of different vascular beds and species (reviewed in [36, 42, 44]). Dohi et al. [10] have shown in mesenteric resistance arteries of the spontaneously hypertensive rat (SHR) that angiotensin II induced vascular endothelin production augments contractility. Threshold concentrations of endothelin have been shown to sensitize vascular smooth muscle to, for example, norepinephrine and serotonin $[10,67]$. In line with these findings, Webb et al. [74] have demonstrated in rabbit aorta that angiotensin II induced contractions can be inhibited with an endothelin receptor antagonist (BQ123).

In addition to the vasoconstrictive effects of endothelin, the peptide has been shown to be positive inotropic in isolated adult rat cardiomyocytes, with an $\mathrm{EC}_{50}$ of $50 \mathrm{pM}[27,34]$. The positive inotropic effect of endothelin is mediated by sensitizing of cardiac myofilaments for calcium (in part due to endothelin-induced intracellular alkalosis) [27, 34, 36]. Both endothelin-mediated (direct and indirect) vasoconstrictive effects and positive inotropic effects might contribute to hypertension in animals or men.

\section{In vivo studies}

Yanagisawa et al. [76] were the first to demonstrate a marked increase in blood pressure after intravenous administration of $1 \mathrm{nmol} / \mathrm{kg}$ endothelin in the rat. The sustained and long-lasting increase in blood pressure is preceded by a transient vasodilatation most probably due to stimulation of release of endothelium-derived relaxing facor, atrial natriuretic factor, or prostacyclin $[42,76]$. Subsequent studies showed dose-dependent increases in blood pressure as well as a very long duration of action in comparison to angiotensin II (duration of action $>2 \mathrm{~h}$ after an intravenous bolus of $2 \mathrm{nmol} /$ $\mathrm{kg}$ ) [45]. Calcium channel blockers antagonized effectively the chronic phase of increase in blood pressure [45]. Mortensen et al. [49] demonstrated that chronic intravenous administration for 7 days causes a dose-dependent, reversible hypertension in rats. Captopril has been shown to control endothelin-induced hypertension, indicating that stimulation of the renin-angiotensin system may be involved in endothelin-induced hypertension [47]. When dietary sodium intake was manipulated, the same investigators demonstrated the endothelin-infusion model of hypertension to be salt dependent [48]. In prehypertensive Dahl-salt sensitive rats reactivity (isometric contraction of vascular rings, increase in intracellular calcium) to endothelin was enhanced, and in hypertensive Dahl-salt sensitive rats medullary endothelin concentrations were increased in comparsion to salt resistant control animals [18].

Plasma endothelin levels were surprisingly lower in SHR and stroke-prone SHR in comparison to normotensive control rats, whereas deoxycorticosterone acetate (DOCA) salt sensitive rats had normal plasma endothelin levels [66]. Since the vascular reactivity for endothelin was increased in DOCA-salt sensitive rats, endothelin might play a role in sodium overload hypertension [66], possibly due to a decrease in plasma endothelin clearance [77]. Overall, there have been conflicting reports with regard to vascular sensitivity in different vascular beds and different strains of rats $[42,43]$.

In addition, there is good evidence that endothelin plays a role in central cardiovascular func- 
tion. Increases in cerebrospinal endothelin levels are associated with pronounced hypertension and, on the other hand, phenylephrine-induced increase in blood pressure has been shown to cause a decrease in cerebrospinal endothelin levels [50]. Very recent studies have investigated the effect of endothelin receptor A antagonists on blood pressure. Bazil et al. [3] demonstrated that the endothelin receptor $\mathrm{A}$ antagonist $\mathrm{BQ} 123$ inhibits the pressor response of endothelin-1 but not that of endothelin-3. Administration of BQ123 produced a mild antihypertensive effect in low- to normal-renin (DOCA-salt sensitive and SHR) but not in highrenin (two-kidney, one-clip, and aortic ligated rats) models of hypertension [3]. Nishikibe et al. [52] demonstrated antihypertensive efficacy of BQ123 in stroke-prone SHR, a model of malignant hypertension, but not in normotensive controls or SHR. The results of Bazil et al. [3] and those of Batra et al. [2] suggest that not only endothelin receptor A but also endothelin receptor B is involved in vasoconstrictive responses of endothelin. Pollock et al. [54] reported the interesting observation that BQ123 completely inhibits the pressor response of endothelin in Sprague-Dawley rats but is unable to affect the renal vasoconstrictor effects (decreases in glomerular filtration rate, renal plasma flow, increases in renal vascular resistance). Endothelin had inconsistent effects on cardiac output in intact animals: transient increase in cardiac output and sustained decrease in cardiac output in most reports in conscious or anesthetized rats, dogs, and cats $[17,22,24,30,35,38,40,46,55,73]$. Cardiac output in the intact animal is influenced by many different factors, including endothelin-induced increases in peripheral resistance, direct positive inotropic effects, hormonal effects of endothelin, and most importantly by constriction of the coronary arteries with subsequent ischemia. Neubauer et al. [51] demonstrated a parallel decrease of coronary flow and cardiac performance after administration of endothelin, using an isolated perfused rat heart. Despite a decrease in cardiac output and a marked increase of peripheral resistance isovolumic $\mathrm{d} p / \mathrm{d} t_{\max }$ was slightly increased in anesthetized rats [35]. The effects of intravenous endothelin are not necessarily representative of the effects of endothelin in situ, where an autocrine/paracrine mode of action is predominant. Therefore a dysregulation of local endothelin secretion might nevertheless, by means of its direct positive inotropic effects, contribute to hypertension.

Another important mechanism for endothelininduced blood pressure regulation may be the wellknown renal effects of endothelin: dose-dependent decreases in glomerular filtration rate, decreases in renal plasma flow, and increases in filtration fraction in the anesthetized rat and anesthetized dog and in the isolated perfused rat kidney, whereas the fractional excretion of sodium remains either unaffected or is moderately increased depending on the dose of endothelin and the animal model employed $[1,28,33,41,65]$. Natriuresis induced by low doses of endothelin $[20,28]$ may be counterregulatory to the vasoconstrictive effects of endothelin.

Judging from the above results, endothelin may play a role in hypertension (via its vasoconstrictive, positive inotropic effects, stimulation of aldosterone secretion, and affecting central cardiovascular function), and in the development of some forms of acute renal failure [33, 61]. At present, endothelin seems to contribute most to salt-sensitive forms of hypertension.

\section{Human studies}

Forearm blood flow is diminished in a dose-dependent manner with a long duration of action (in comparison to angiotensin II) after intra-arterial administration $[8,29]$, demonstrating that endothelin is a vasoconstrictor in man. Vierhapper et al. [71] demonstrated that exogenous endothelin causes hypertension in man. Yokokawa et al. [78] demonstrated that patients with malignant hemangioendothelioma are hypertensive and have elevated plasma endothelin levels. After surgery both blood pressure and plasma endothelin levels normalized. However, in one patient with recurrent disease both plasma endothelin levels and blood pressure increased again. Likewise, plasma endothelin levels are markedly elevated in women with preeclampsia/eclampsia and in patients with severe hypertension $[11,58,69,75]$. In addition, endothelin may be involved in cyclosporine A induced hypertension since it has been shown that cyclosporine releases endothelin from human endothelial cells [7]. In rats treated chronically with cyclosporine an increased urinary excretion of endothelin has been shown [4]. A cyclosporine-induced increase in plasma endothelin levels in hypertensive cardiac transplant patients has been suggested [19], but the role of endothelin in cyclosporine-treated hypertensive patients has clearly to be investigated in further and more detailed studies. The endothelin receptor A antagonist BQ123 has been shown to be protective in cyclosporine-induced nephrotoxicity possibly by blocking the cyclosporine-induced vasoconstriction of the afferent arteriole $[12,37]$. Finally, a role of endothelin in the erythropoietin-induced hyper- 
tension of, for example, dialysis patients has been put forward [6].

Measurement of plasma endothelin levels in essential and secondary hypertension showed controversial results (normal or elevated concentrations) $[9,32,57,59,60,62,70]$. These differences may be due to different assays or patient samples. Lerman et al. [39] have shown that plasma endothelin levels are correlated with atherosclerosis, probably explaining part of the difference between different groups of hypertensive patients. In general, the validity of plasma endothelin levels as a marker of action is questionable since endothelin is thought to act predominantly in an autocrine/ paracrine fashion. Supporting this assumption, Wagner et al. [72] have recently demonstrated a markedly higher endothelin release in abluminal direction in cultured human endothelial cells.

In addition to its cardiovascular effects (e.g. vasoconstriction/positive inotropy), its well-known (co-)mitogenic/atherogenic effects may be of importance as causative factor or with regard to progression of the disease [36]. Specifically, endothelin has been shown to promote proliferation of smoothmuscle cells, mesangial cells, and cardiomyocytes $[23,63,64]$ - implicating a possible role of endothelin in the formation of atherosclerotic plaques as well as in cardiac growth and hypertrophy. Interestingly a role of endothelin in primary pulmonary hypertension has recently been suggested [15].

\section{Conclusions}

The demonstrated in vitro, in vivo, and human data are supportive of but in no way prove a role of endothelin in hypertension. Inhibitors of endothelin-converting enzyme and/or endothelin receptor antagonists are expected to contribute to the ultimate solution of this important question, especially when results become available during long-term treatment with these drugs. Short-term studies may not allow conclusions with regard to the role of endothelin in hypertension because of the known prolonged action of the peptide. Therefore the potential of endothelin receptor antagonists and/or endothelin-converting enzyme inhibitors as antihypertensive agents in human hypertension must be elucidated in further studies in experimental animals and in man.

Acknowledgements. This work was supported by grants from the Paul-Martini-Stiftung, Bonn, and from the Doktor Robert Pfleger-Stiftung, Bamberg.

\section{References}

1. Badr KF, Murray JJ, Breyer MD, Takahashi K, Inagami $\mathrm{T}$, Harris RC (1989) Mesangial cell, glomerular and renal vascular responses to endothelin in the rat kidney. J Clin Invest 83:336-342

2. Batra VK, McNeill JR, Xu J, Wilson TW, Gopalakrishnan V (1993) $\mathrm{ET}_{\mathrm{B}}$ receptors on aortic smooth muscle cells of spontaneously hypertensive rats. Am J Physiol 264: C479-C484

3. Bazil MK, Lappe RW, Webb RL (1992) Pharmacologic characterization of an endothelin $\mathrm{A}_{\mathrm{A}}\left(\mathrm{ET}_{\mathrm{A}}\right)$ receptor antagonist in conscious rats. J Cardiovasc Pharmacol 20:940-948

4. Benigni A, Perico N, Ladny JR, Imberti O, Bellizzi L, Remuzzi G (1991) Increased urinary excretion of endothelin-1 and its precursors, big endothelin-1, in rats chronically treated with cyclosporine. Transplantation 52:175-177

5. Bloch KD, Friedrich SP, Lee M-E, Eddy RL, Shows TB, Quertermous T (1989) Structural organization and chromosomal assignment of the gene encoding endothelin. J Biol Chem 264:10851-10857

6. Bode-Böger SM, Böger RH, Kuhn M, Radermacher J, Frölich JC (1992) Endothelin release and shift in prostaglandin balance are involved in the modulation of vascular tone by recombinant erythropoietin. J Cardiovasc Pharmacol 20 (Suppl 12): 25-28

7. Bunchman TE, Brookshire CA (1991) Cyclosporine-induced synthesis of endothelin by cultured human endothelial cells. J Clin Invest 88:310-314

8. Clarke JG, Benjamin N, Larkin SW, Webb DJ, Davies GJ, Maseri A (1989) Endothelin is a potent long-lasting vasoconstrictor in men. Am J Physiol 257: H2033-H2035

9. Davenport AP, Ashby MJ, Easton P, Ella S, Bedford J, Dickerson C, Nunez DJ, Capper SJ, Brown MJ (1990) A sensitive radioimmunoassay measuring endothelin-like immunoreactivity in human plasma: comparison of levels in patients with essential hypertension and normotensive control subjects. Clin Sci 78:261-264

10. Dohi Y, Hahn AWA, Boulanger CM, Bühler F, Lüscher TF (1992) Endothelin stimulated by angiotensin II augments contractility of spontaneously hypertensive rat resistance arteries. Hypertension 19:131-137

11. Florijin KW, Derkx FHM, Visser W, Hofmann HJA, Rosmalen FMA, Wallenburg HCS, Schalekamp MADH (1991) Elevated plasma levels of endothelin in pre-eclampsia. J Hypertension 9: S166-S167

12. Fogo A, Hellings SE, Inagami T, Kon V (1992) Endothelin receptor antagonism is protective in in vivo acute cyclosporine toxicity. Kidney Int 42:770-774

13. Furchgott RF, Zawadzki JV (1980) The obligatory role of endothelial cells in the relaxation of arterial smooth muscle by acetylcholine. Nature 288:373-376

14. Furchgott RF, Vanhoutte PM (1989) Endothelium-derived relaxing and contracting factors. FASEB J 3:2007-2018

15. Giaid A, Yanagisawa M, Langleben D, Michel RP, Levy R, Shennib H, Kimura S, Masaki T, Duguid WP, Stewart DJ (1993) Expression of endothelin-1 in the lungs of patients with pulmonary hypertension. N Engl J Med 328:1732-1739

16. Gillespie MN, Owasoyo JO, McMurtry IF, O'Brien RF (1986) Sustained coronary vasoconstriction provoked by a peptidergic substance released from endothelial cells in culture. J Pharmacol Exp Ther 236:339-343

17. Goetz KL, Wang BC, Madwed JB, Zhu JL, Leadley RJ Jr (1988) Cardiovascular, renal, and endocrine responses to intravenous endothelin in conscious dogs. Am J Physiol 255: R1064-R1068

18. Goligorsky MS, Ijjima K, Morgan M, Yangisawa M, Masaki T, Lin L, Nasjletti A, Kaskel F, Frazer M, Badr KF (1991) 
Role of endothelin in the development of Dahl hypertension. J Cardiovasc Pharmacol 17 [Suppl 7]: 484-491

19. Haas GJ, Wooding-Scott M, Binkley PF, Myerowitz PD, Kelley R, Cody RJ (1993) Effects of successful cardiac transplantation on plasma endothelin. Am J Cardiol 71:237-240

20. Harris PJ, Zhuo J, Mendelsohn FAO, Skinner SL (1991) Haemodnamic and renal tubular effects of low doses of endothelin in anesthetized rats. J Physiol 433:25-39

21. Hickey KA, Rubanyi G, Paul RJ, Highsmith RF (1985) Characterization of a coronary vasoconstrictor produced by cultured endothelial cells. Am J Physiol 248: C550-C556

22. Hinojosa-Laborde C, Osborn JW, Cowley AW (1989) Hemodynamic effects of endothelin in conscious rats. Am J Physiol 256: H1742-H1746

23. Hirata Y, Takagi Y, Fukuda Y, Marumo F (1989) Endothelin is a potent mitogen for rat vascular smooth muscle cells. Atherosclerosis 78:225-228

24. Hoffman A, Grossman E, Öhman KP, Marks E, Keiser HR (1989) Endothelin induces an initial increase in cardiac output associated with selective vasodilation in rats. Life Sci $45: 249-255$

25. Ignarro LJ (1989) Biological actions and properties of endothelium-derived nitric oxide formed and released from artery and vein. Circ Res 65:1-21

26. Inoue A, Yanagisawa M, Kimura S, Kasuya $Y$, Miyauchi $T$, Goto K, Masaki T (1989) The human endothelin family: three structurally and pharmacologically distinct isopeptides predicted by three separate genes. Proc Natl Acad Sci USA 86:2863-2867

27. Kelly RA, Eid H, Krämer BK, O’Neill M, Liang BT, Reers M, Smith TW (1990) Endothelin enhances the contractile responsiveness of adult rat ventricular myocytes to calcium by a pertussis toxin-sensitive pathway. J Clin Invest $86: 1164-1171$

28. King AJ, Brenner BM, Anderson S (1989) Endothelin: a potent renal and systemic vasoconstrictor peptide. Am J Physiol 256: F1051-F1058

29. Kiowski W, Lüscher TF, Linder L, Bühler FR (1991) Endothelin-1-induced vasoconstriction in humans. Circulation $83: 469-475$

30. Kitayoshi T, Watanabe T, Shimamoto N (1989) Cardiovascular effects of endothelin in dogs: positive inotropic action in vivo. Eur J Pharmacol 166:519-522

31. Kloog Y, Ambar I, Sokolovsky M, Kochva E, Wollberg Z, Bdolah A (1988) Sarafotoxin, a novel vasoconstrictor peptide: phosphoinositide hydrolysis in rat heart and brain. Science 242:268-270

32. Kohno M, Yasunari K, Murakawa K-I, Yokokawa K, Horio T, Fukui T, Takeda T (1990) Plasma immunoreactive endothelin in essential hypertension. Am J Med 88:614-618

33. Kon V, Yoshioka T, Fogo A, Ichikawa I (1989) Glomerular actions of endothelin in vivo. J Clin Invest 83:1762-1767

34. Krämer BK, Smith TW, Kelly RA (1991) Endothelin and increased contractility in adult rat ventricular myocytes. Role of intracellular alkalosis induced by activation of the protein kinase C-dependent $\mathrm{Na}^{+}-\mathrm{H}^{+}$exchanger. Circ Res $68: 269-279$

35. Krämer BK, Beyer ME, Nerz S, Hoffmeister HM, Seipel L (1992) Ciculatory and myocardial effects of endothelin. J Vasc Res 29:154

36. Krämer BK, Nishida M, Kelly RA, Smith TW (1992) Endothelins. Myocardial actions of a new class of cytokines. Circulation 85:350-356

37. Lanese DM, Conger JD (1993) Effects of endothelin receptor antagonist on cyclosporine-induced vasoconstriction in isolated rat renal arterioles. J Clin Invest 91:2144-2149
38. Le Monnier de Gouville AC, Mondot S, Lippton H, Hyman A, Cavero I (1990) Hemodynamic and pharmacological evaluation of the vasodilator and vasoconstrictor effects of endothelin-1 in rats. J Pharmacol Exp Ther 252:300-311

39. Lerman A, Edwards BS, Hallett JW, Heublein DM, Sandberg SM, Burnett JC (1991) Circulating and tissue endothelin immunoreactivity in advanced atherosclerosis. N Engl J Med 325:997-1001

40. Lippton HL, Hauth TA, Summer WR, Hyman AL (1989) Endothelin produces pulmonary vasoconstriction and systemic vasodilation. J Appl Physiol 66:1008-1012

41. Lopez-Farre A, Montanes I, Milles I, Lopez-Novoa JM (1989) Effect of endothelin on renal function in rats. Eur J Pharmacol 163:187-189

42. Lüscher TF, Bock HA, Yang Z, Diederich D (1991) Endothelium derived relaxing and contracting factors: perspectives in nephrology. Kidney Int 39:575-590

43. Lüscher TF, Boulanger CM, Dohi Y, Yang Z (1992) Endothelium-derived contracting factors. Hypertension 19:117-130

44. Masaki T, Kimura S, Yanagisawa M, Goto K (1991) Molecular and cellular mechanism of endothelin regulation. Implications for vascular function. Circulation 84:1457-1468

45. Miyauchi T, Ishikawa T, Tomobe Y, Yanagisawa M, Kimura S, Sugishita Y, Ito I, Goto K, Masaki T (1989) Characteristics of pressor response to endothelin in spontaneously hypertensive and Wistar-Kyoto rats. Hypertension 14:427-434

46. Mortensen LH, Fink GD (1990) Hemodynamic effect of human and rat endothelin administration into conscious rats. Am J Physiol 258: H362-H368

47. Mortensen LH, Fink GD (1992) Captopril prevents chronic hypertension produced by infusion of endothelin-1 in rats. Hypertension 19:676-680

48. Mortensen LH, Fink GD (1992) Salt-dependency of endothelin-induced, chronic hypertension in concious rats. Hypertension 19:549-554

49. Mortensen LH, Pawlowski CM, Kanagy NL, Fink GD (1990) Chronic hypertension produced by infusion of endothelin in rats. Hypertension 15:729-733

50. Mosqueda-Garcia R, Inagami T, Appalsamy M, Sugiura M, Robertson RM (1992) Endothelin as a neuropeptide. Cardiovascular effects in the brainstem of normotensive rats. Circ Res 72:20-35

51. Neubauer S, Ertl G, Haas U, Pulzer F, Kochsiek K (1990) Effects of endothelin-1 in isolated perfused rat heart. J Cardiovase Pharmacol 16:1-8

52. Nishikibe M, Tsuchida S, Okada M, Fukuroda T, Shimamoto K, Yano M, Ishikawa K, Ikemoto F (1993) Antihypertensive effect of a newly synthesized endothelin antagonist, BQ123 , in a genetic hypertensive model. Life Sci 52:717-724

53. O'Brien RF, Robbins RJ, McMurtry IF (1987) Endothelial cells in culture produce a vasoconstrictor substance. J Cell Physiol 132:263-270

54. Pollock DM, Opgenorth TJ (1993) Evidence for endothelininduced renal vasoconstriction independent of $\mathrm{ET}_{\mathrm{A}}$ receptor activation. Am J Physiol 264: R222-R226

55. Rohmeiss $P$, Photiadis J, Rohmeiss S, Unger T (1990) Hemodynamic actions of intravenous endothelin in rats: comparison with sodium nitroprusside and methoxamine. Am J Physiol 258: H337-H346

56. Rubanyi GM, Vanhoutte PM (1985) Hypoxia releases a vasoconstrictor substance from the canine vascular endothelium. J Physiol 364:45-56

57. Saito Y, Nakao K, Mukoyama M, Imura H (1990) Increased plasma endothelin level in patients with essential hypertension. N Engl J Med 322:205 
58. Samuels P, Steinfeld JD, Braitman LE, Rhoa MF, Cines DB, McCrae KR (1993) Plasma concentration of endothelin-1 in women with cocaine-associated pregnancy complications. Am J Obstet Gynecol 168:528-533

59. Schiffrin EL, Thibault G (1991) Plasma endothelin in human essential hypertension. Am J Hypertension 4:303-308

60. Schrader J, Tebbe U, Borries M, Ruschitzka F, Schoel G, Kandt M, Warneke G, Züchner C, Weber MH, Neu U, Rath W, Henning HV (1990) Plasma-Endothelin bei Normalpersonen und Patienten mit nephrologisch-rheumatologischen und kardiovaskulären Erkrankungen. Klin Wochenschr 68:774-779

61. Shibouta Y, Suzuki N, Shino A, Matsumoto H, Terashita Z-I, Kondo K, Nishikawa K (1990) Pathophysiological role of endothelin in acute renal failure. Life Sci 46:1611-1618

62. Shichiri M. Hirata Y, Ando K, Emori T, Ohta K, Kimoto S, Ogura M, Inoue A, Marumo F (1990) Plasma endothelin levels in hypertension and chronic renal failure. Hypertension 15:493-496

63. Shubeita HE, McDonough PM, Harris AN, Knowlton KU, Glembotski CC, Brown JH, Chien KR. (1990) Endothelin induction of inositol phospholipid hydrolysis, sarcomere assembly, and cardiac gene expression in ventricular myocytes. J Biol Chem 265:20555-20562

64. Simonson MS, Wann S, Mene P, Dubyak GR, Kester M, Nakazato Y, Sedor JR, Dunn MR (1989) Endothelin stimulates phospholipase $\mathrm{C}, \mathrm{Na} / \mathrm{H}$ exchange, $\mathrm{c}$-fos expression, and mitogenesis in rat mesangial cells. J Clin Invest 83:708-712

65. Stacy DL, Scott JW, Granger JP (1990) Control of renal function during intrarenal infusion of endothelin. Am J Physiol 258: F1232-F1236

66. Suzuki N, Miyauchi T, Tomobe Y, Matsumoto H, Goto K, Masaki T, Fujino M (1990) Plasma concentrations of endothelin-1 in spontaneously hypertensive rats and DOCAsalt hypertensive rats. Biochem Biophys Res Commun 167:941-947

67. Tabuchi Y, Nakamura M, Rakugi H, Nagano M, Ogihara T (1989). Endothelin enhances adrenergic vasoconstriction in perfused rat mesenteric arteries. Biochem Biophys Res Commun 159:1304-1308

68. Takasaki C, Tamiya N, Bdolah A, Wollberg Z, Kochva E (1988) Sarafotoxins S6: several isoforms from Atractaspis engaddensis (burrowing asp) venom that affect the heart. Toxicon 26:543-548

69. Taylor RN, Varma M, Teng NNH, Roberts JM (1990) Women with preeclampsia have higher plasma endothelin levels than women with normal pregnancies. J Clin Endocrinol Metab 71:1675-1677
70. Tsunoda K, Abe K, Yoshinaga K (1991) Endothelin in hemodialysis-resistant hypertension. Nephron 59:687-688

71. Vierhapper H, Wagner O, Nowotny P, Waldhäusl W (1990) Effect of endothelin-1 in man. Circulation 81:1415-1418

72. Wagner OF, Christ G, Wojta J, Vierhapper H, Parzer S, Nowotny PJ, Schneider B, Waldhäusl W, Binder BR (1992) Polar secretion of endothelin-1 by cultured endothelial cells. J Biol Chem 267:16066-16068

73. Watanabe $T$, Kusumoto $\mathrm{K}$, Kitayoshi $T$, Shimamoto $N$ (1989) Positive inotropic and vasoconstrictive effects of endothelin-1 in in vivo and in vitro experiments: characteristics and the role of L-type calcium channels. J Cardiovasc Pharmacol 13 [Suppl 5]: S108-S111

74. Webb ML, Dickinson KEJ, Delaney CL, Liu ECK, Serafino R, Cohen RB, Monshizadegan H, Moreland S (1992) The endothelin receptor antagonist, $\mathrm{BQ}-123$, inhibits angiotensin II-induced contractions in rabbit aorta. Biochem Biophys Res Commun 185:887-892

75. Widimsky J, Horky K, Dvorakova J (1991) Plasma endothelin-1,2 levels in mild and severe hypertension. J Hypertension 9: S194-S195

76. Yanagisawa M, Kurihara H, Kimura S, Tomobe $\mathrm{Y}$, Kobayashi M, Mitsui Y, Yazaki Y, Goto K, Masaki T (1988) A novel potent vasoconstrictor peptide produced by vascular endothelial cells. Nature 332:411-415

77. Yokokawa K, Kohno M, Murakawa K, Yasunari K, Inoue T, Takeda T (1990) Effects of endothelin on blood pressure and renal hemodynamics in DOCA-salt hypertensive rats under conscious and unrestrained conditions. Clin Exp Hypertens [A] 12:1049-1062

78. Yokokawa K, Tahara H, Kohno M, Murakawa K, Yasunari $K$, Nakagawa $K$, Hamada $T$, Otani $S$, Yanagisawa $M$, Takeda T (1991) Hypertension associated with endothelinsecreting malignant hemangioendothelioma. Ann Intern Med 114:213-215

Received: Iuly 12, 1993

Returned for revision: August 17, 1993

Accepted: September 7, 1993

Priv.-Doz. Dr. med. B.K. Krämer

Klinik und Poliklinik für Innere Medizin II

Klinikum der Universität Regensburg

D-93042 Regensburg

Germany 